\title{
Could it be a secondary hypertension?
}

\author{
Maria Chiara Matteucci \\ From 71st Congress of the Italian Society of Pediatrics. Joint National Meeting SIP, SIMGePeD, Study Group \\ on Pediatric Ultrasound, SUP Study Group on Hypertension \\ Rome, Italy. 4-6 June 2015
}

High percentage of hypertensive children younger than 15 years of age show secondary hypertension. Correction of the underlying disorder may cure the hypertension and avoid the need for prolonged drug therapy.

When to suspect a secondary hypertension at initial evaluation:

- No family history of hypertension in a thin child

- Age younger than 10 years and prepubertal stage

- Acute rise in blood pressure previously normal

- Severe hypertension (SBP/DBP $\geq 99$ th percentile plus $5 \mathrm{mmHg}$ )

- Mild hypertension (SBP/DBP $\geq 95$ th percentile plus $5 \mathrm{mmHg}$ ) in systemic disease

- Nocturnal hypertension, reduced nocturnal dipping or diastolic hypertension at 24-hour BP monitoring

- Urological or congenital renal pathology

- Symptons of sympathetic overactivity

- Ambigous genitalia

- Edema, high serum creatinine and/or abnormal urinalysis

- Systemic disorders with secondary glomerulonephritis

- Neonatal umbelical catheterization

- Abdominal auscultatory bruit

- Upper extremities hypertension and lower extremities hypotension.

- Familiar chronic or congenital renal disease

If suspicion is consistent for a secondary hypertension the following diagnostic studies are needed:

- Renal ultrasonography as recommended by the National High Blood Pressure Education Program Working Group in Children and adolescent (NHBPEP), 2004 [1]

Correspondence: mchiara.matteucci@opbg.net

Department of Nephrology and Urology, Bambino Gesù Children Research Hospital, Rome 00153, Italy

C 2015 Matteucci. This is an Open Access article distributed under the terms of the Creative Commons Attribution License (http.// creativecommons.org/licenses/by/4.0), which permits unrestricted use, distribution, and reproduction in any medium, provided the original work is properly cited. The Creative Commons Public Domain Dedication waiver (http://creativecommons.org/publicdomain/ zero/1.0/) applies to the data made available in this article, unless otherwise stated.
- 99mTc-dimercaptosuccinic acid (DMSA) renal scan, sensitive study for renal cortical loss and scarring

- Plasma renin activity

- Plasma and urine catecholamines

- Renovascular imaging as magnetic resonance angiography, computed tomographic angiography, duplex Doppler ultrasonography and standard intraarterial angiography

- Echocardiography

Published: 30 September 2015

\section{Reference}

1. National High Blood Pressure education Program Working Group on High Blood Pressure in Children and adolescent: The fourth report on the diagnosis, evaluation, and treatment of high blood pressure in children and adolescent. Pediatrics 2004, 114(2 Suppl 4th Report):555-576.

doi:10.1186/1824-7288-41-S2-A49

Cite this article as: Matteucci: Could it be a secondary hypertension? Italian Journal of Pediatrics 2015 41(Suppl 2):A49.

Submit your next manuscript to BioMed Central and take full advantage of:

- Convenient online submission

- Thorough peer review

- No space constraints or color figure charges

- Immediate publication on acceptance

- Inclusion in PubMed, CAS, Scopus and Google Scholar

- Research which is freely available for redistribution \\ ( Biomed Central}

